\title{
Treatment of Experimental Encephalomyelitis with a Novel Chimeric Fusion Protein of Myelin Basic Protein and Proteolipid Protein
}

\author{
Eileen A. Elliott, ${ }^{*}$ Hugh I. McFarland, ${ }^{\ddagger}$ Steven H. Nye, ${ }^{*}$ Roxanne Cofiell, ${ }^{\star}$ Todd M. Wilson, ${ }^{*}$ James A. Wilkins, ${ }^{*}$ \\ Stephen P. Squinto, ${ }^{*}$ Louis A. Matis, ${ }^{*}$ and John P. Mueller* \\ Departments of $*$ Immunobiology, Molecular Development, and Process Development, Alexion Pharmaceuticals, Inc., New Haven, \\ Connecticut 06511; and ${ }^{\ddagger}$ Laboratory of Immunology, National Institutes of Allergy and Infectious Diseases, National Institutes of Health, \\ Bethesda, Maryland 20892
}

\begin{abstract}
It has been shown that peripheral $\mathrm{T}$ cell tolerance can be induced by systemic antigen administration. We have been interested in using this phenomenon to develop antigenspecific immunotherapies for $\mathrm{T}$ cell-mediated autoimmune diseases. In patients with the demyelinating disease multiple sclerosis (MS), multiple potentially autoantigenic epitopes have been identified on the two major proteins of the myelin sheath, myelin basic protein (MBP) and proteolipid protein (PLP). To generate a tolerogenic protein for the therapy of patients with MS, we have produced a protein fusion between the 21.5- $\mathrm{kD}$ isoform of MBP (MBP21.5) and a genetically engineered form of PLP ( $\triangle$ PLP4). In this report, we describe the effects of treatment with this agent (MP4) on clinical disease in a murine model of demyelinating disease, experimental autoimmune encephalomyelitis (EAE). Treatment of SJL/J mice with MP4 after induction of EAE either by active immunization or by adoptive transfer of activated $T$ cells completely prevented subsequent clinical paralysis. Importantly, the administration of MP4 completely suppressed the development of EAE initiated by the cotransfer of both MBP- and PLP-activated T cells. Prevention of clinical disease after the intravenous injection of MP4 was paralleled by the formation of long-lived functional peptide-MHC complexes in vivo, as well as by a significant reduction in both MBP- and PLP-specific T cell proliferative responses. Mice treated with MP4 were resistant to disease when rechallenged with an encephalitogenic PLP peptide emulsified in CFA, indicating that MP4 administration had a prolonged effect in vivo. Administration of MP4 was also found to markedly ameliorate the course of established clinical disease. Finally, MP4 therapy was equally efficacious in mice defective in Fas expression. These results support the conclusion that MP4 protein is highly effective in suppressing disease caused by multiple neuroantigen epitopes in experimentally induced demyelinating disease. (J. Clin. Invest. 1996. 98:1602-1612). Key words: autoimmunity $\bullet$ apoptosis $\cdot \mathrm{T}$ cells $\bullet$ tolerance $\bullet$ immunomodulators
\end{abstract}

\footnotetext{
Address correspondence to John P. Mueller, Department of Immunobiology, Alexion Pharmaceuticals, Inc., 25 Science Park, Box 15, New Haven, CT 06511. Phone: 203-776-1790; FAX: 203-772-3655; E-mail: jmuel61478@aol.com

Received for publication 26 April 1996 and accepted in revised form 23 July 1996.
}

The Journal of Clinical Investigation

Volume 98, Number 7, October, 1996, 1602-1612

\section{Introduction}

Experimental autoimmune encephalomyelitis $(\mathrm{EAE})^{1}$ is a $\mathrm{CD}^{+} \mathrm{T}$ cell-mediated inflammatory demyelinating disease of the central nervous system that can be induced in genetically susceptible nonhuman primates and rodents $(1,2)$. In most murine models of EAE, the response of encephalitogenic $\mathrm{T}$ cells is directed against either of two myelin antigens, myelin basic protein (MBP) or proteolipid protein (PLP). EAE can be induced by injection of mouse spinal cord homogenate, MBP, PLP, or peptide fragments of these major myelin protein components emulsified in adjuvant (1,3-13). Alternatively, EAE can be elicited by the adoptive transfer of activated MBP or PLP-specific $\mathrm{CD}^{+} \mathrm{T}$ cells into normal syngeneic recipient mice $(9,14-17)$. In the $\mathrm{SJL} / \mathrm{J}$ mouse strain, the disease is characterized by progressive ascending paralysis, followed by periods of remission and subsequent relapses $(9,14,15)$. The resulting clinical signs and pathological course involving central nervous system inflammation and demyelination have many similarities to the human demyelinating disease multiple sclerosis (MS; 1$)$.

Previous work has shown that it is possible to prevent EAE by the administration of myelin-associated antigens in a manner that is dependent on the form and the route of antigen administration $(6,18-24)$. Recent studies have further demonstrated several mechanisms by which systemic antigen administration can lead to specific downregulation of T cell-mediated immune responses in vivo, which include peripheral $\mathrm{T}$ cell deletion, the induction of anergy, or the preferential amplification of $\mathrm{T}$ cell subsets that produce antiinflammatory cytokines (immune deviation; 12, 16-26).

We have been examining antigen-specific approaches to the therapy of $\mathrm{T}$ cell-mediated human autoimmune diseases, including MS. There is considerable evidence that T cell-mediated autoimmunity has a major role in the pathogenesis of demyelination in MS. Investigations on the autoantigens that elicit $\mathrm{T}$ cell responses in MS have centered on the protein components of the myelin sheath. For example, several laboratories have explored the specificity of the $\mathrm{T}$ cell response in the cerebrospinal fluid and the peripheral blood from individuals with MS, focusing on the immune response to the major proteins of myelin, MBP and PLP, which constitute $~ 30$ and $\sim 50 \%$ of the protein in myelin, respectively. Immunodominant epitopes of MBP in MS patients have been localized to residues 84-102 and 143-168 (27-32). Two hydrophilic regions of PLP,

1. Abbreviations used in this paper: APC, antigen-presenting cell; EAE, experimental autoimmune encephalomyelitis; LNC, lymph node cells; MBP, myelin basic protein; MS, multiple sclerosis; PCC, pigeon cytochrome c; PI, propidium iodide; PLP, proteolipid protein. 
residues $30-49$ and $180-199$, were recently demonstrated to be immunodominant regions recognized by human peripheral $\mathrm{T}$ cell populations after primary in vitro stimulation with native PLP (33). However, results from several laboratories have further revealed a marked heterogeneity of human $\mathrm{T}$ cell proliferative responses to MBP and PLP with respect to epitope recognition, MHC restriction, and T cell receptor usage $(13,28$, 30, 34-47). Furthermore, there is evidence for progressive diversification of the $\mathrm{T}$ cell repertoire during the course of autoimmune disease. This phenomenon, referred to as determinant or epitope spreading, may result from the exposure of the immune system to additional antigenic determinants at the initial site of inflammation (48-51). For example, several groups have proposed that either the myelin degradation initiated by a primary $\mathrm{T}$ cell response to an epitope on MBP during the initial paralytic episode or perhaps the subsequent remyelination process may expose additional encephalitogenic epitopes to the peripheral immune system, and these in turn may trigger relapses (48-56).

In this light, immunosuppressive strategies that target multiple autoantigenic epitopes in patients with established MS might be expected to achieve optimal clinical benefit. Therefore, we have been exploring the potential efficacy of protein rather than peptide-based therapies to induce immune tolerance. To this end, we have engineered a recombinant chimeric fusion protein termed MP4 that encodes multiple autoantigenic epitopes from the $21.5-\mathrm{kD}$ isoform of MBP, as well as from PLP, and therefore has the potential to induce tolerance to multiple peptide epitopes simultaneously.

In the present study, we examine the efficacy of intravenous therapy with MP4 in a murine model of EAE. We demonstrate that MP4 can be effectively processed in vivo to epitopes derived from both the MBP and PLP proteins. Intravenous therapy with MP4 resulted in markedly diminished T cell responses to MBP and PLP, and completely prevented EAE induced by the cotransfer of MBP- and PLP-specific encephalitogenic T cell populations. Mice treated with MP4 were resistant to the reinduction of disease after immunization with an encephalitogenic form of PLP, indicating that a durable form of tolerance had been established. Importantly, MP4 treatment also markedly ameliorated the course of established EAE. Finally, MP4 administration was highly effective in preventing EAE in Fas-deficient mice, consistent with the concept that intravenous antigen administration may induce peripheral tolerance by more than one molecular mechanism. Overall, these findings suggest that intravenous therapy with MP4 may significantly benefit the treatment of human $\mathrm{T}$ cell-mediated autoimmune demyelinating disease.

\section{Methods}

Construction of an expression plasmid for fusion protein MP4. The genetic fusion encoding the full-length 21.5-kD isoform of MBP (57) and $\triangle$ PLP4 (Elliott, E.A., R. Cofiell, T.M. Wilson, C.S. Raine, J.A. Wilkins, S.P. Squinto, L.A. Matis, and J.P. Mueller, manuscript in preparation) was constructed as follows. A DNA segment containing an appropriately spaced prokarytoic ribosome-binding site and the $\triangle$ PLP4 gene (Fig. $1 A$ ) was inserted into the bacterial expression plasmid pET22b-MBP21.5 (57). This created a dicistronic operon for the independent expression of MBP21.5 and $\triangle \mathrm{PLP} 4$. To construct an expression plasmid (pMP4) for a chimeric protein consisting of the fulllength 21-kD isoform of MBP and $\triangle \mathrm{PLP} 4$, the dicistronic construct was digested with AatII-XhoI and ligated to a synthetic AatII-XhoI linker/adapter, creating an in-frame fusion of MBP21.5 and $\triangle$ PLP4. Proper genetic construction of MP4 was confirmed by DNA sequence analysis. The expression plasmid pMP4 encodes a protein comprising full-length MBP21.5, seven amino acids introduced by the construction procedure (amino acids LGGLEDP), followed by $\triangle$ PLP4, as shown in Fig. $1 \mathrm{~B}$. The MP4 fusion protein is predicted to have a molecular weight of $40.8 \mathrm{kD}$.

Escherichia coli expression system. The expression plasmid pMP4 was introduced by electroporation into E. coli strain W3110(DE3). Expression of genes in $\mathrm{pET} 22 \mathrm{~b}$ relies on transcription from the phage $\mathrm{T} 7$ promoter mediated by T7 RNA polymerase (58). The phage polymerase was supplied by $E$. coli host strains harboring a $\lambda$-lysogen carrying the $\mathrm{T} 7$ gene encoding the phage RNA polymerase under control of the lacUV5 promoter. Inductions were performed as described previously (57). Briefly, small-scale cultures or fermentations in a 20.01 Applikon (Foster City, CA) glass vessel were grown in Terrific Broth medium at $37^{\circ} \mathrm{C}$ to an $\mathrm{OD}_{600}$ of 0.9 or 10 , respectively, and recombinant protein expression was induced by the addition of $0.4 \mathrm{mM}$ isopropyl- $\beta$-D-thiogalactopyranoside, and growth continued for an additional $3 \mathrm{~h}$. Cells were harvested, and cell pellets were frozen at $-80^{\circ} \mathrm{C}$ overnight. Pellets were resuspended in $20 \mathrm{mM}$ Na citrate/1.0 $\mathrm{mM}$ EDTA, $\mathrm{pH} 5.0,(10 \mathrm{ml} / \mathrm{g}$ wet $\mathrm{wt})$, and were disrupted by passage through a Microfluidizer (Microfluidics, Newton, MA). Unlysed cells were removed by centrifugation at $3,000 \mathrm{rpm}$, and the insoluble material was collected by centrifugation at $16,000 \mathrm{rpm}$.

Production of MP4. Insoluble pellets were resuspended with an Ultraturrax (Tekmar Co., Cincinnati, $\mathrm{OH}$ ) homogenizer and washed for $1 \mathrm{~h}$ at $4^{\circ} \mathrm{C}$ in wash buffer $(10 \mathrm{ml} / \mathrm{g}$ wet wt; $1.5 \mathrm{M}$ guanidine hydrochloride $/ 0.5 \mathrm{M} \mathrm{NaCl} / 20 \mathrm{mM}$ sodium phosphate, $\mathrm{pH}$ 5.0) with intermittent mixing. The lysate was centrifuged as described above, and the supernatant was discarded. The pellet was extracted in extraction buffer $(10 \mathrm{ml} / \mathrm{g}$ wet wt; $1.5 \mathrm{M}$ guanidine hydrochloride/ $0.5 \mathrm{M} \mathrm{NaCl} / 20 \mathrm{mM}$ sodium phosphate, $\mathrm{pH}$ 5.0) with intermittent mixing, centrifuged, and passed through a $0.45-\mathrm{mm}$ Polycap AS filter (Whatman Chemical Co., Clifton, NJ). The extracted MP4 was applied to an affinity column (200-400 medium/ml packed bed volume) of chelating Sepharose 6B Fast Flow (Pharmacia Fine Chemicals, Piscataway, NJ), charged with $0.1 \mathrm{M} \mathrm{NiCl}_{2}$, and equilibrated with buffer $\mathrm{A}$ ( $6 \mathrm{M}$ guanidine hydrochloride/ $0.5 \mathrm{M} \mathrm{NaCl} / 20 \mathrm{mM}$ sodium phosphate $/ 1 \mathrm{mM}$ 2-mercaptoethanol, $\mathrm{pH}$ 7.2). The bacterial lysate was adjusted to $\mathrm{pH} 7.2$ with $1.0 \mathrm{~N}$ $\mathrm{NaOH}$, and $1 \mathrm{mM}$ 2-meracaptoethanol was added. The sample was applied to the column and washed with 10 bed vol of buffer A. The column was washed successively with 12 bed vol of buffer A using a $\mathrm{pH}$ step gradient ( $\mathrm{pH}$ 7.2-5.3). MP4 protein was eluted with buffer E (6 M urea/ $0.5 \mathrm{M} \mathrm{NaCl} / 0.02 \mathrm{M}$ sodium phosphate, $\mathrm{pH} 3.5$ ) while monitoring OD at $280 \mathrm{~nm}$. MP4 protein fractions were pooled, concentrated by ultrafiltration, and exchanged into Milli $\mathrm{Q}$ water using an Amicon Inc. (Beverly, MA) stirred cell and PM10 membrane. For in vivo studies, MP4 was further purified by reverse-phase HPLC, as described previously (57). Briefly, MP4 was denatured and reduced in $6 \mathrm{M}$ gaunidine- $\mathrm{HCl} / 50 \mathrm{mM}$ DTT, $\mathrm{pH} 8.0$, and applied to to a $1 \mathrm{~cm} \times$ $25 \mathrm{~cm}$ length C4 Vydac (Hesperia, CA) reverse-phase HPLC column equilibrated in $65 \%$ solvent $\mathrm{A}\left(50 \%\right.$ formic acid $\left./ 50 \% \mathrm{H}_{2} \mathrm{O}\right)$ and $35 \%$ solvent B (50\% acetonitrile $/ 50 \%$ formic acid) with a flow rate of 4.0 $\mathrm{ml} / \mathrm{min}$. The bound MP4 was eluted with a linear gradient of solvent B (35-90\%). Pooled MP4 fractions were concentrated in a Rotavap (Brinkman Instruments, Inc., Westbury, NY) after several washes with deionized water to remove residual formic acid. Finally, the sample was concentrated using an Amicon stirred cell at $4^{\circ} \mathrm{C}$ with 6 vol of deionized water. Proteins were visualized on $4-20 \%$ gradient SDSpolyacrylamide gels stained with Coomassie blue. Western blot analysis was performed using polyclonal anti-human PLP or monoclonal anti-human MBP primary antibodies (Serotec Ltd., Oxford, UK) and detected with horseradish peroxidase-labeled secondary antibodies using an enhanced chemiluminescence detection system (Amersham, Arlington Heights, IL). The concentration of MP4 protein was estimated by measuring the $\mathrm{OD}$ at $280 \mathrm{~nm}$, based on the assumption that an $\mathrm{OD}$ of 1.0 corresponds to $0.89 \mathrm{mg} / \mathrm{ml}$. The endotoxin content in 
the preparations used in these studies was $<1.0 \mathrm{EU} / \mathrm{mg}$. Amino-terminal protein sequence corresponded to the first 25 amino acids of MP4 with an alanine at position 1. Recombinant MBP21.5 and $\Delta$ PLP4 were purified by $\mathrm{Ni}^{2+}$ affinity chromatography, as previously described (57).

Mice. Female SJL/J and MRL lpr/lpr mice, 6-12 wk old, were purchased from The Jackson Laboratory (Bar Harbor, ME). All mice were housed in the Alexion animal care facility and were maintained on standard laboratory food and water ad libitum. Paralyzed animals were afforded easier access to food and water. All procedures were performed under an approved protocol in accordance with the animal use guidelines set by the Animal Care and Use Committee of Alexion Pharmaceuticals, Inc. Wild-type and Fas-deficient mice (lpr/lpr) were obtained by crossing SJL/J with MRL lpr/lpr mice, back-crossing to $\mathrm{SJL} / \mathrm{J}$ for two generations, and then intercrossing. The $l p r$ genotype of offspring was determined by PCR as previously described (59).

Immunization with recombinant PLP proteins and peptides. PLP- and MBP-specific peptides were synthesized and purified at the Louisiana State University Medical Center Biotechnology Core Laboratories (New Orleans, LA). The amino acid composition was verified by mass spectrometry, and purity ( $>98 \%$ ) was assessed by HPLC. Mice were immunized subcutaneously in the left flank at three sites with a total of $0.15 \mathrm{ml}$ emulsion containing either $400 \mu \mathrm{g}$ ovalbumin, $300 \mu \mathrm{g}$ MP4, $400 \mu \mathrm{g}$ bovine MBP (Sigma Chemical Co., St. Louis, MO), or $150 \mu \mathrm{g}$ PLP peptide 139-151 and an equal volume of CFA containing $150 \mu \mathrm{g}$ of Mycobacterium tuberculosis H37Ra (Difco Laboratories, Detriot, MI). Immediately after and $48 \mathrm{~h}$ later, pertussis toxin (List Biologicals, Campbell, CA) was injected intravenously (300 ng/injection). The standard inoculation to reinduce disease in SJL/J mice was PLP peptide 139-151 in CFA at the same concentrations given subcutaneously over the right flank with pertussis on days 0 and 2. Mice were monitored routinely, and a mean clinical score was assigned to each group using the following scale: grade 0 , no abnormality; grade 1 , limp tail; grade 2 , limp tail and slow to right upon being turned over; grade 3 , hindlimb weakness; grade 4, paralysis of both hindlimbs; and grade 5, moribund. Mean day of onset was calculated as the mean day that the animals showed initial signs.

Adoptive transfer of EAE. Donor SJL/J mice were immunized subcutaneously with $150 \mu \mathrm{g}$ PLP peptide $139-151$ or $400 \mu \mathrm{g}$ bovine MBP, as described above. $10 \mathrm{~d}$ later, draining lymph node cells (LNC) were harvested and stimulated $\left(8 \times 10^{6} / \mathrm{ml}\right)$ with $10 \mu \mathrm{g} / \mathrm{ml}$ of PLP peptide $139-151$ or $25 \mu \mathrm{g} / \mathrm{ml}$ MBP peptide $84-104$ for $4 \mathrm{~d}$. T cell blasts were harvested by Ficoll-Hypaque gradient centrifugation, washed twice with PBS, and injected via the orbital vein of naive anesthetized recipients. Mice received $10^{7}$ activated PLP-specific or $2.5 \times 10^{7}$ activated MBP-specific T cells in $0.1 \mathrm{ml}$ PBS. For the cotransfer experiments, each animal was injected intravenously with $0.1 \mathrm{ml}$ of PBS containing $2.5 \times 10^{7} \mathrm{MBP}$-specific and $10^{7}$ PLP-specific $\mathrm{T}$ cells.

Induction of antigen-specific tolerance. In experiments assessing the prevention of EAE, antigen-specific tolerance was induced by orbital vein injection of $150 \mu \mathrm{g} \Delta \mathrm{PLP} 4,300 \mu \mathrm{g}$ MBP21.5, $300 \mu \mathrm{g}$ MP4, or $300 \mu \mathrm{g}$ pigeon cytochrome c (PCC) dissolved in DWFI (5\% dextrose water for injection) twice daily on days 5, 7, and 9 after active induction with MP4, $\triangle$ PLP4, or PLP peptide 139-151, or on days 3, 5, and 7 after cell transfer for adoptively transferred EAE. In the adoptive transfer experiments assesssing the treatment of established EAE, MP4, or PCC were given at the same dosage twice a day on days 24,26 , and 28 after the first episode of clinical disease.

I- $A^{s}$-restricted $T$ cell lines. PLP-specific T cell lines L100 and L101 were generated by a previously described method (60) from LNCs of wild-type and Fas-deficient mice, respectively, that had been immunized with PLP peptide 139-151. Briefly, the cells were restimulated in complete medium without exogenous IL-2 (RPMI 1640 supplemented with $2 \mathrm{mM}$ glutamine $/ 50 \mathrm{~mm}$ 2-mercaptoethanol $/ 100 \mu \mathrm{g} / \mathrm{ml}$ streptomycin $/ 100 \mathrm{U} / \mathrm{ml}$ penicillin $/ 10 \%$ FCS) in the presence of PLP peptide 139-151 $(10 \mu \mathrm{g} / \mathrm{ml})$ and mitomycin C-treated SJL/J splenic antigen-presenting cells (APCs). After $48 \mathrm{~h}$, T cell blasts were puri- fied over a Ficoll-Hypaque gradient and expanded into medium containing $50 \mathrm{U} / \mathrm{ml}$ recombinant IL-2 (Biogen, Cambridge, MA). The I-A ${ }^{\mathrm{s}}$-restricted, MBP 87-99-specific T cell line L1 was kindly provided by Stefan Brocke (National Institutes of Health, Bethesda, $\mathrm{MD})$. This $\mathrm{T}$ cell line was grown in complete medium at a concentration of $10^{6}$ cells $/ \mathrm{ml}$ and restimulated every $14 \mathrm{~d}$ using $5-10 \mu \mathrm{g} / \mathrm{ml}$ MBP peptide 84-104 presented on mitomycin C-treated syngeneic splenocytes as APCs. The cultures were supplemented intermittently with $10 \mathrm{U} / \mathrm{ml} \mathrm{IL}-2$.

Antigen-specific T cell proliferation. The in vitro proliferative responses of purified whole $\mathrm{T}$ cell populations were determined in 96well flat-bottom microtiter plates. LNCs were harvested and T cells were purified by negative selection over T cell columns (R \& D Systems, Minneapolis, MI). Viable T cells were cultured at $4 \times 10^{5}$ cells/ well with an equal number of mitomycin $\mathrm{C}$-treated syngeneic splenocytes as APCs. Cells were incubated in $0.2 \mathrm{ml}$ RPMI containing $10 \%$ FCS and the indicated concentrations of peptides or proteins for $72 \mathrm{~h}$ at $37^{\circ} \mathrm{C}$ in $5 \% \mathrm{CO}_{2}$. Cultures were pulsed with $1.0 \mu \mathrm{Ci}\left[{ }^{3} \mathrm{H}\right]$ thymidine for the final $16 \mathrm{~h}$ of culture. The plates were harvested onto glass fiber filters with an automated sample harvester. Cultures were run in triplicate, and the results were expressed as $\Delta$ cpm [(mean cpm of stimulated cultures)-(mean cpm of control cultures)]. For proliferation assays with long-term in vitro-cultured $\mathrm{T}$ cell lines specific for PLP peptide 139-151 or MBP peptide 87-99, T cells were incubated at $5 \times 10^{4}$ cells per well in flat-bottom microtiter plates with various numbers of mitomycin $\mathrm{C}$-treated SJL/J spleen cells as APCs. Cultures were pulsed for $16 \mathrm{~h}$ with $1 \mu \mathrm{Ci}\left[{ }^{3} \mathrm{H}\right]$ thymidine after a $72-\mathrm{h}$ incubation.

Flow cytometric analyses. The extent of apoptosis after anti-CD3 (2C11; kindly provided by Jeff Bluestone, University of Chicago, Chicago, IL) or anti-TCR- $\alpha \beta$ (H57-597; Pharmingen, San Diego, CA) stimulation of activated $\mathrm{T}$ cell lines was assessed by propidium iodide (PI) staining, as previously described (61). Cells were analyzed with a FACScan ${ }^{\circledR}$ flow cytometer (Becton Dickinson \& Co., Mountain View, CA).

\section{Results}

Expression and purification of recombinant MP4. To determine whether a single polypeptide could simultaneously induce tolerance to $\mathrm{T}$ cells specific for distinct epitopes, we prepared a model recombinant chimeric protein, designated MP4, by linking in tandem the synthetic gene encoding the complete human 21.5-kD isoform of MBP (57) and a gene deletion of PLP designated $\triangle$ PLP4 (Elliott, E.A., R. Cofiell, T.M. Wilson, C.S. Raine, J.A. Wilkins, S.P. Squinto, L.A. Matis, and J. Mueller, manuscript in preparation; see Fig. $1, A$ and $B$ in this paper). The $\triangle$ PLP4 construct encompasses hydrophilic domains of PLP encoding multiple T cell epitopes, as determined by analyses of PLP-specific T cell populations from MS patients (13, 31, 33, 37, 40-47). Plasmid pMP4 was transformed into E. coli strain W3110(DE3), and MP4 was identified by Coosmassie blue staining and Western blotting with anti-human MPB- and PLP-specific antibodies. Bacteria containing MP4 in pET22b produced a significant fraction of their total protein $(\sim 10 \%)$ as MP4 in the insoluble fraction of the lysed E. coli pellet (data not shown). Insoluble pellets from cells that contained the MP4 gene were solubilized in guanidine, and they were purified using a metal affinity column. The column was eluted with a decreasing $\mathrm{pH}$ step gradient. MP4 was further purified by reverse-phase HPLC, as described in Methods. After dialysis into water, the MP4 protein was examined by SDS-PAGE. As shown in Fig. $1 C$, the MP4 protein migrated predominantly as a single species at a molecular mass of $\sim 40 \mathrm{kD}$. These proce- 
A

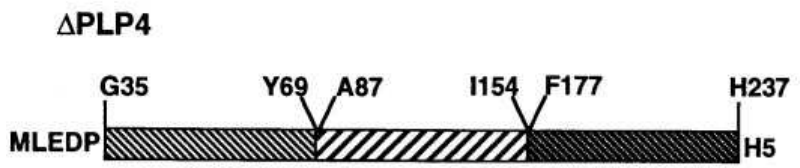

B

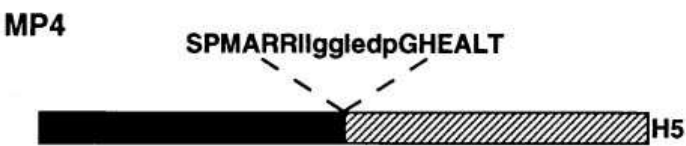

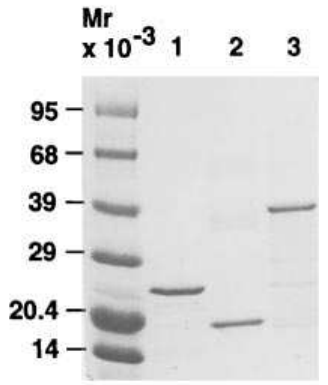

Figure 1. Construction and expression of MP4. (A) Schematic diagram of the gene deletion $\triangle$ PLP4 (Elliott, E.A., R. Cofiell, T.M. Wilson, C.S. Raine, J.A. Wilkins, S.P. Squinto, L.A. Matis, and J.P. Mueller, manuscript in preparation). The $\triangle$ PLP4 chimeric gene encodes the three hydrophilic domains of PLP, as defined by Weimbs and Stoffel (68). The regions of the native PLP protein present in $\triangle \mathrm{PLP} 4$ (hatched and cross-hatched regions) are displayed by the amino acid sequence number of the native protein at the junctions between the fused hydrophilic domains. The amino acids at the $\mathrm{NH}_{2^{-}}(M L E D P)$ and $\mathrm{COOH}$ termini (H5) were introduced during construction. (B) Map of the MP4 construct. A genetic fusion construct encoding the full-length 21.5-kD isoform of MBP (dark

shaded region) and $\triangle \mathrm{PLP} 4$ (cross-hatched region) was constructed as described in the Methods. The sequences displayed show the junction between MBP21.5 and $\triangle$ PLP4 (capital letters). The lowercase amino acids were introduced during construction. (C) SDS-PAGE analysis of partially purified preparations of MBP21.5, $\triangle \mathrm{PLP} 4$, and MP4. Concentrations of MBP21.5, $\triangle \mathrm{PLP} 4$, and MP4 were determined assuming an OD of 1.0 at $280 \mathrm{~nm}$ corresponding to $1.78,0.69$, and $0.89 \mathrm{mg} / \mathrm{ml}$, respectively. Molecular weight standards (lane 1$)$ and samples (2.0 $\mu \mathrm{g}$ ) of MBP21.5 (lane 2), $\triangle$ PLP4 (lane 3), and MP4 (lane 4) used throughout this study were subjected to SDS-PAGE (4-20\% gradient polyacrylamide gel) under reducing conditions. Proteins were visualized by staining with Coomassie brilliant blue.

dures produced MP4 protein that was at least $90 \%$ pure, as judged by SDS-PAGE and analytical HPLC analysis.

Induction of EAE by immunization with recombinant MP4. The immunodominant, encephalitogenic epitope for $\mathrm{SJL} / \mathrm{J}$ mice lies within residues $139-151$ of the PLP protein and accounts for the majority of $\mathrm{CD}^{+} \mathrm{T}$ cell reactivity in $\mathrm{SJL} / \mathrm{J}$ mice immunized with spinal cord homogenate $(6,7)$. Therefore, to determine the encephalitogenicity of MP4, SJL/J mice were immunized with PLP peptide 139-151 or MP4 emulsified in CFA, and were evaluated for clinical signs of EAE. Immunization of SJL/J mice with MP4 produced disease with a clinical course and severity quite similar to the acute disease observed after immunization with PLP peptide 139-151 (Fig. 2, A and $B$, open circles). All mice uniformly exhibited signs of disease within $16 \mathrm{~d}$ after immunization with either MP4 or PLP peptide 139-151. The disease was characterized by initial weight loss, followed sequentially by tail paralysis, hindlimb weakness, decreased righting ability, and hindlimb paralysis. Control mice immunized with ovalbumin showed no signs of clinical disease and had no weight loss during the course of the experiment.

Intravenous administration of MP4 inhibits EAE mediated by MBP-and PLP-specific T cells. Systemic antigen administration has been shown to induce immunological tolerance. Several mechanisms have been described to account for this effect, including clonal deletion (18-26). For example, intravenous administration of MBP after transfer of $\mathrm{CD}^{+} \mathrm{MBP}$-specific transgenic $\mathrm{T}$ cells into naive B10.PL $\left(\mathrm{H}-2^{\mathrm{u}}\right)$ mice was recently shown to prevent the onset of clinical EAE in mice by mediating $\mathrm{T}$ cell deletion (21). We therefore asked whether the systemic administration of MP4 could prevent the development of actively induced clinical EAE in SJL/J $\left(\mathrm{H}-2^{\mathrm{s}}\right)$ mice. As shown in Fig. 2, twice per day intravenous administration of
MP4 on days 5, 7, and 9 after immunization with PLP139-151 or MP4 resulted in complete protection of mice from both the initial and relapsing episodes of clinical disease (Fig. 2, $A$ and $B$, closed circles). The effect of recombinant protein treatment on disease inhibition appeared to be long lasting. Thus, after cessation of the therapy, the treated animals manifested no evidence of disease for $>100 \mathrm{~d}$ after the original immunization (data not shown). These data demonstrate that administration of MP4 can effectively prevent the onset of clinical EAE after immunization with an encephalitogenic peptide of PLP.

To investigate whether administration of MP4 could block disease induced by another protocol, we tested the ability of recombinant MBP21.5, $\triangle \mathrm{PLP} 4$, as well as MP4, to abrogate adoptively transferred EAE in recipient mice. Although only weakly induced by direct immunization with MBP, severe EAE can be precipitated in SJL/J mice by the adoptive transfer of activated MBP-specific T cells. EAE was thus induced in $\mathrm{SJL} / \mathrm{J}$ mice by the adoptive transfer of activated $\mathrm{T}$ cells after stimulation with either MBP peptide 84-104 or PLP peptide 139-151 (Fig. 3). Transfer of $2.5 \times 10^{7}$ MBP84-104-activated T cells elicited a characteristic relapsing-remitting course of EAE $(14,15)$. Mice that received MBP-specific T cells were fully protected by intravenous treatment with recombinant MBP21.5 or MP4 (Fig. 3 A). Conversely, intravenous administration of $\triangle \mathrm{PLP} 4$ or MP4 on days 3,5 , and 7 after adoptive transfer of $10^{7}$ PLP139-151-activated T cells completely prevented the development of clinical EAE (Fig. $3 B$ ). In the control PCC-treated group, all the recipients developed severe EAE. More importantly, all the mice in the PCC-treated group and none of the mice in the MBP21.5, $\triangle \mathrm{PLP} 4$, or MP4treated groups developed relapses. These results demonstrate that treatment with recombinant antigens after transfer of encephalitogenic $\mathrm{T}$ cells, but before the development of clinical 

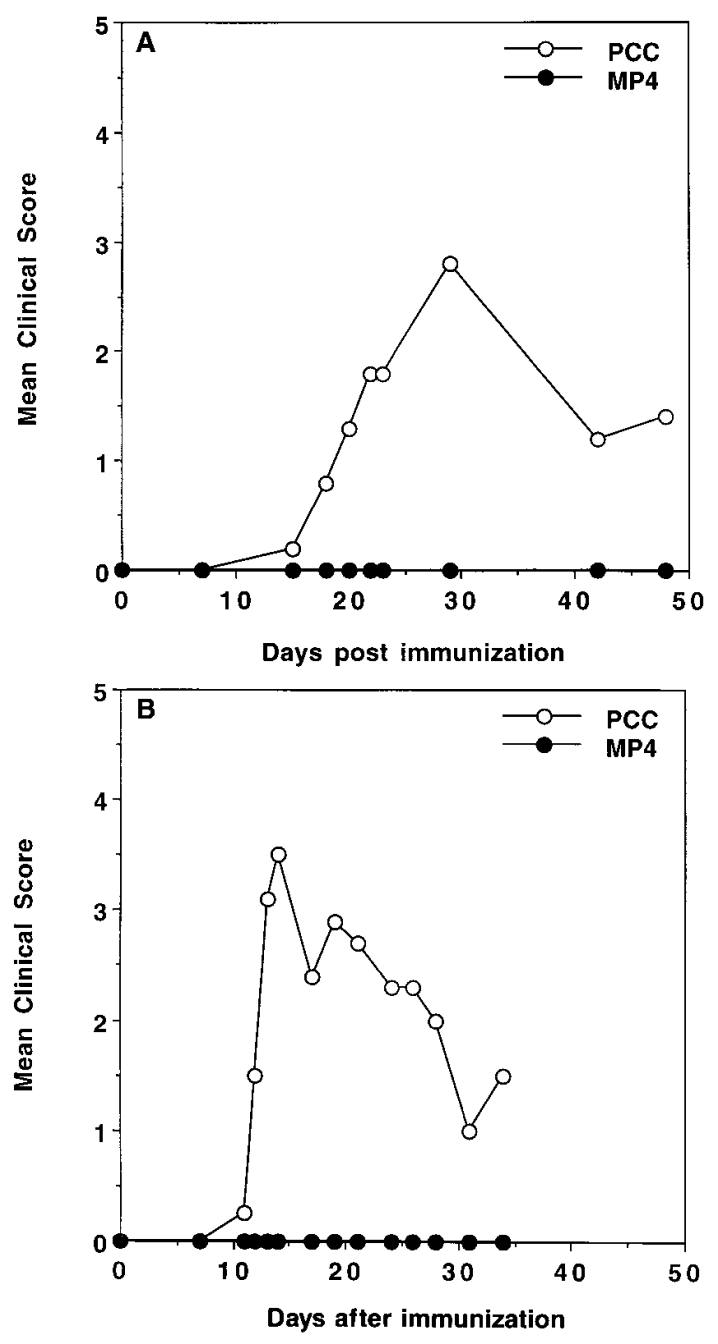

Figure 2. Prevention of active EAE by the administration of MP4. Mice were immunized with $150 \mu \mathrm{g}$ of PLP peptide 139-151/CFA $(A)$ or $300 \mu \mathrm{g}$ of MP4/CFA $(B)$ on day 0 . Mice also received $300 \mathrm{ng}$ of pertussis toxin intravenously on days 0 and 2. Mice received two intravenous injections of MP4 $(300 \mu \mathrm{g})$ or PCC $(300 \mu \mathrm{g})$ on days 5, 7, and 9 after immunization. Mice were monitored, and a mean clinical score was assigned for each group of six mice. Each experiment is representative of at least three separate experiments.

disease, prevents the induction of both acute and relapsing EAE. Therefore, the MP4 protein prevents disease caused by direct immunization or the adoptive transfer of encephalitogenic $\mathrm{T}$ cells.

Effect of recombinant myelin antigens on treatment of a cotransfer model of EAE. To evaluate whether MP4 would ameliorate disease mediated concurrently by $\mathrm{T}$ cell populations with distinct antigen specificities, we performed cotransfer experiments with both activated MBP- and PLP-specific activated T cells. As shown in Fig. 4, mice that received a mixture of $2.5 \times 10^{7} \mathrm{MBP} 84-104-$ specific T cells and 107 PLP139151-specific $\mathrm{T}$ cells developed disease $\sim 10 \mathrm{~d}$ after adoptive transfer. All mice that received either recombinant MBP21.5 treatment alone or $\triangle \mathrm{PLP} 4$ treatment alone on days 3,5 , and 7 after $\mathrm{T}$ cell transfer developed chronic EAE, although with a slightly delayed onset relative to the control PCC-treated mice. In contrast, treatment with MP4 resulted in complete in-
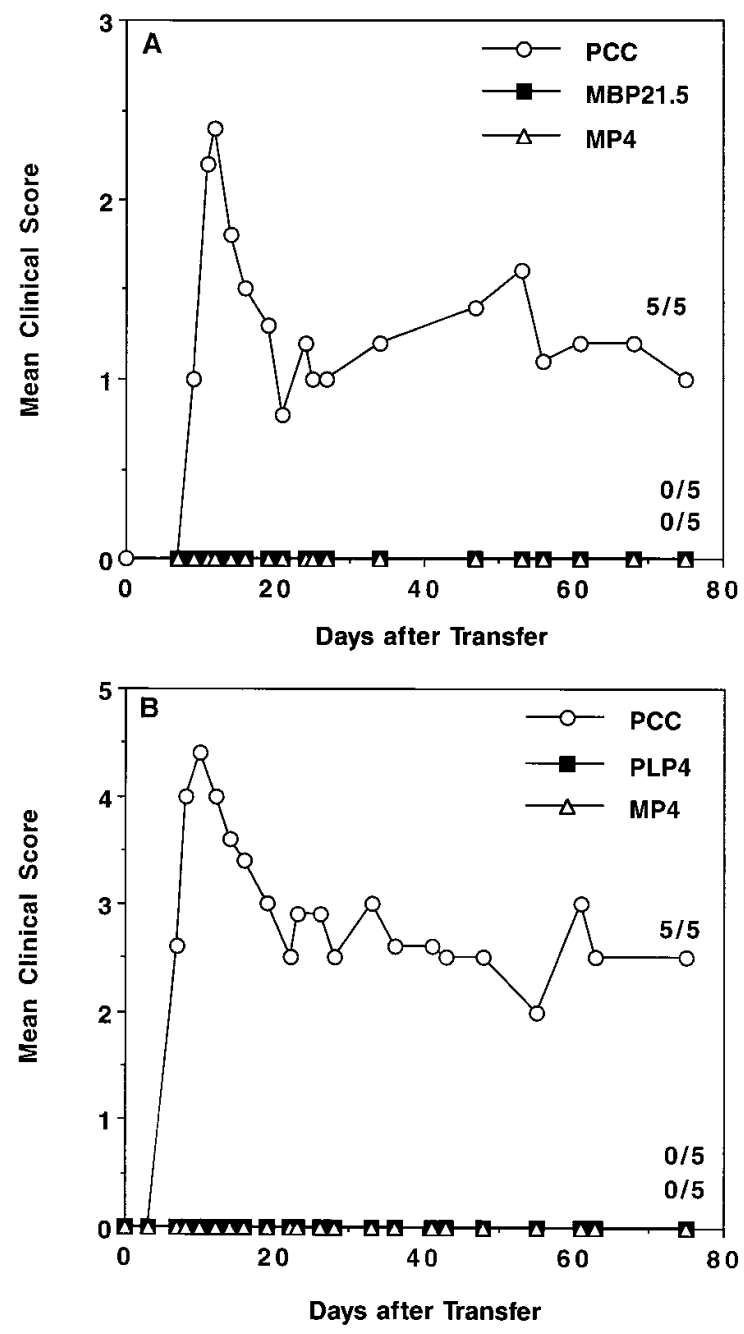

Figure 3. Prevention of adoptive transfer EAE by MP4. Activated T cells from MBP/CFA- $(A)$ or PLP139-151 peptide/CFA-immunized mice $(B)$ were transferred into naive recipients on day 0 . Recipient mice received two intravenous injections of PCC $(300 \mu \mathrm{g})$, MBP21.5 $(300 \mu \mathrm{g}), \Delta \mathrm{PLP} 4(150 \mu \mathrm{g})$, or MP4 (300 $\mu \mathrm{g})$ on days 3, 5, and 7 after T cell transfer. The incidence of clinical disease during the observation period is indicated next to the corresponding clinical course. Each experiment is representative of at least three separate experiments.

hibition of acute and relapsing EAE for the entire 100-d period of observation (Fig. 4). Adoptive transfer experiments with MBP- and PLP-specific T cell populations administered individually demonstrated that MBP21.5 and MP4, but not $\triangle \mathrm{PLP} 4$, completely inhibited the development of EAE by transfer of MBP-specific T cells into naive recipients, whereas $\triangle$ PLP4 and MP4, but not MBP21.5, protected mice against EAE mediated by activated PLP-specific T cells (data not shown). These results confirmed the independent encephalitogenic potential of the MBP-and PLP-specific T cell populations used in this study. Overall, these results clearly demonstrate that intravenous administration of a therapeutic polypeptide can be effective in suppressing disease mediated by $\mathrm{T}$ cells specific for more than one autoantigenic epitope.

Diminished antigen-specific proliferation after intravenous therapy with MP4. Inhibition of PLP139-151- and MBP84104-specific T cell responses could, in part, explain the dimin- 


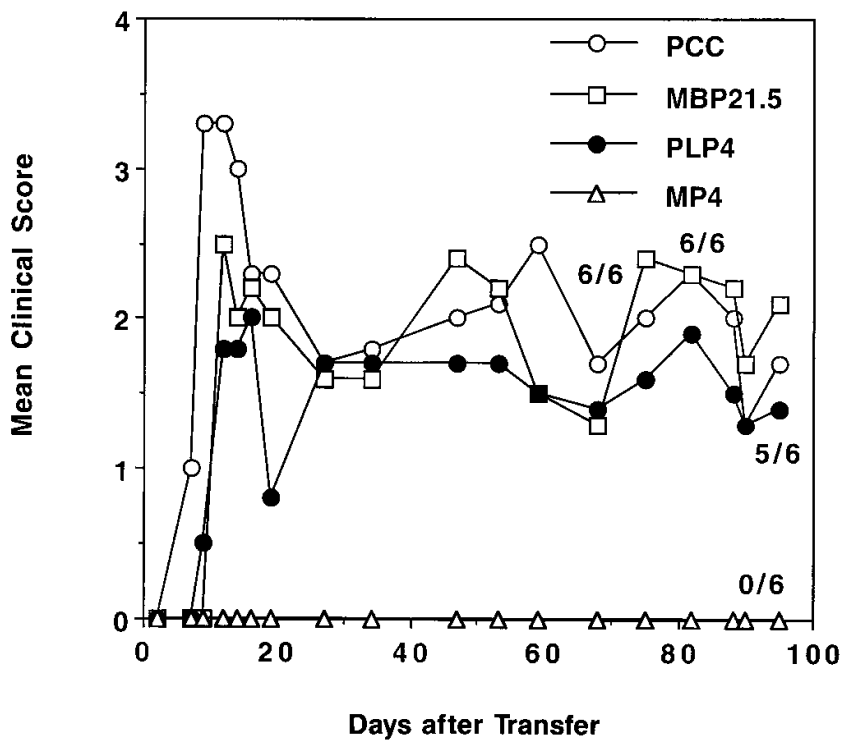

Figure 4. Treatment of EAE induced by cotransfer of MBP- and PLPspecific T cells to naive recipient $\mathrm{SJL} / \mathrm{J}$ mice. A mixture of $2.5 \times 10^{7}$ MBP84-104-specific and 107 PLP139-151-specific T cells were cotransferred to naive recipients, and mice were treated with MBP21.5 $(300 \mu \mathrm{g})$, $\Delta$ PLP4 $(150 \mu \mathrm{g})$, MP4 $(300 \mu \mathrm{g})$, or PCC (300 $\mu \mathrm{g})$ twice daily on days 3, 5, and 7 after $T$ cell transfer. The incidence of clinical disease during the observation period is indicated next to the corresponding clinical course.

Each experiment is representative of at least three separate experiments.

ished clinical paralysis in MP4-treated mice. We therefore determined the level of MBP84-104- and PLP139-151-specific T cell proliferative response in mice that had received MP4 therapy. Approximately $11 \mathrm{~d}$ after MP4 treatment of MP4-immunized mice, $T$ cells were isolated from draining lymph nodes, and proliferative responses against MBP and PLP peptides were determined. As shown in Fig. 5, T cell proliferative responses against both MBP and PLP peptides were significantly inhibited in mice treated with MP4, consistent with the induction of antigen-specific tolerance. The functional capacity of the T cell populations from MP4-treated animals to respond to non-MP4-induced mitogenic signals was confirmed by demonstrating strong proliferation in response to the lectin concanavalin A (Fig. 5).

Susceptibility of MP4-treated mice to reinduction of disease. It has been reported that $\mathrm{SJL} / \mathrm{J}$ mice remain susceptible to reinduction of EAE after recovery from an initial disease episode if reimmunized with PLP peptide 139-151 (62). This response is antigen-specific and occurs with an accelerated time course, typical of a memory response. To test the durability of tolerance induction, we attempted to reinduce EAE in mice previously treated with MP4. After MP4 treatment of PLPimmunized mice, any remaining PLP139-151-specific memory $\mathrm{T}$ cells, as well as any PLP-specific recent thymic emigrants, could respond to a second immunization and thus mediate disease. In these studies, SJL/J mice were initially challenged by immunization with PLP peptide 139-151, and the animals were treated with either PCC or MP4 with the standard protocol described above. As observed in early experiments, all of the PCC-treated animals and none of the MP4-treated animals developed signs of disease (Fig. 6). Approximately 6 wk later, after recovery of the PCC-treated group from the acute phase of

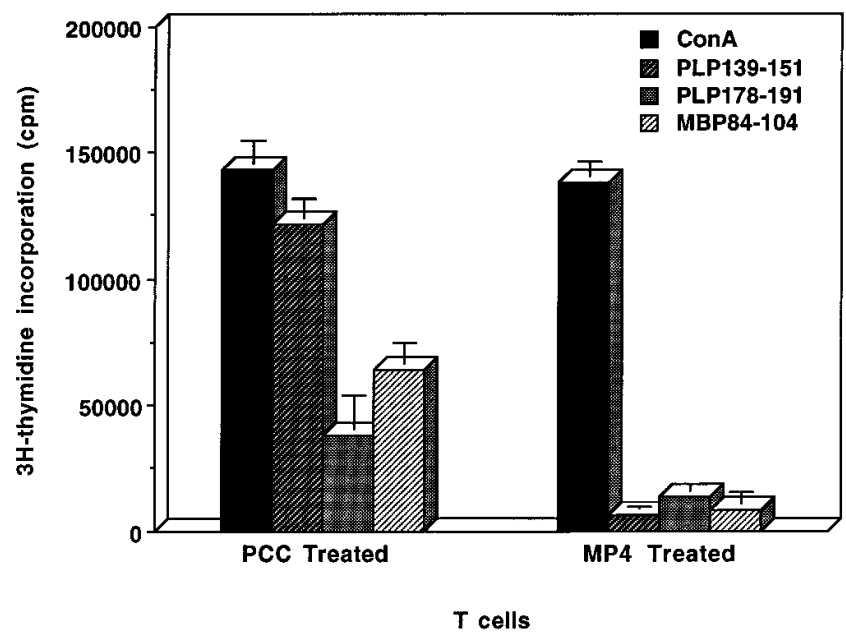

Figure 5. In vivo tolerance induction inhibits MBP and PLP peptide-specific $\mathrm{T}$ cell proliferation. SJL/J mice were treated with MP4 $(300 \mu \mathrm{g})$ or PCC $(300 \mu \mathrm{g})$ twice daily on days 5,7 , and 9 after immunization with MP4/CFA $(300 \mu \mathrm{g}) .20 \mathrm{~d}$ after immunization, draining LNCs were removed and T cells were purified. T cells were stimulated with concanavalin A $(10 \mu \mathrm{g} / \mathrm{ml})$ or an equal number of mitomycin C-treated splenocytes and the indicated peptides $(10 \mu \mathrm{g} / \mathrm{ml})$. Results are expressed as $\Delta \mathrm{cpm}$. Error bars represent the mean \pm SEM of triplicate cultures. The results presented are representative of three separate experiments.

PLP-induced EAE, both groups of mice were rechallenged with PLP139-151 peptide in the adjuvant to reinduce disease. All the mice originally treated with PCC developed a second severe episode of EAE with an accelerated onset (Fig. 6). In contrast, all of the mice in the original MP4-treated group were resistant to reinduction of disease, manifesting virtually no clinical signs of EAE (Fig. 6). The encephalitogenicity of the PLP peptide preparation was further confirmed by its capacity to elicit primary disease in age-matched naive SJL/J mice (Fig. 6, Untreated). These results suggest that MP4 treatment induces a state of durable peripheral $\mathrm{T}$ cell tolerance that renders the animal incapable of mounting a subsequent encephalitogenic $\mathrm{T}$ cell response to myelin autoantigens.

MP4 treatment of established EAE. The previous experiments demonstrated that MP4 therapy could prevent the onset of clinical EAE after active immunization, adoptive transfer of activated $\mathrm{T}$ cells, or reimmunization. We next asked whether administration of MP4 to mice after the onset of the acute phase of EAE would alter the clinical course of the disease. To this end, relapsing EAE was induced by the intraperitoneal transfer of $5 \times 10^{6}$ PLP139-151-specific activated T cells. The onset of disease was observed $\sim 10 \mathrm{~d}$ after adoptive transfer, with the inital remission occurring $\sim 2$ wk thereafter. After the first episode of disease, either MP4 or PCC was administered intravenously to recipient animals twice on days 24,26 , and 28 after cell transfer, and the animals were then followed for the development of clinical relapses. At the time of treatment, both groups of mice were in remission from the initial episode of acute clinical disease. As shown in Fig. 7, MP4 therapy at this time almost completely eliminated subsequent relapses, with only one of six animals showing minimal signs of EAE between 80 and $90 \mathrm{~d}$ after adoptive transfer. In contrast, all six of the control PCC-treated animals developed multiple relapses 


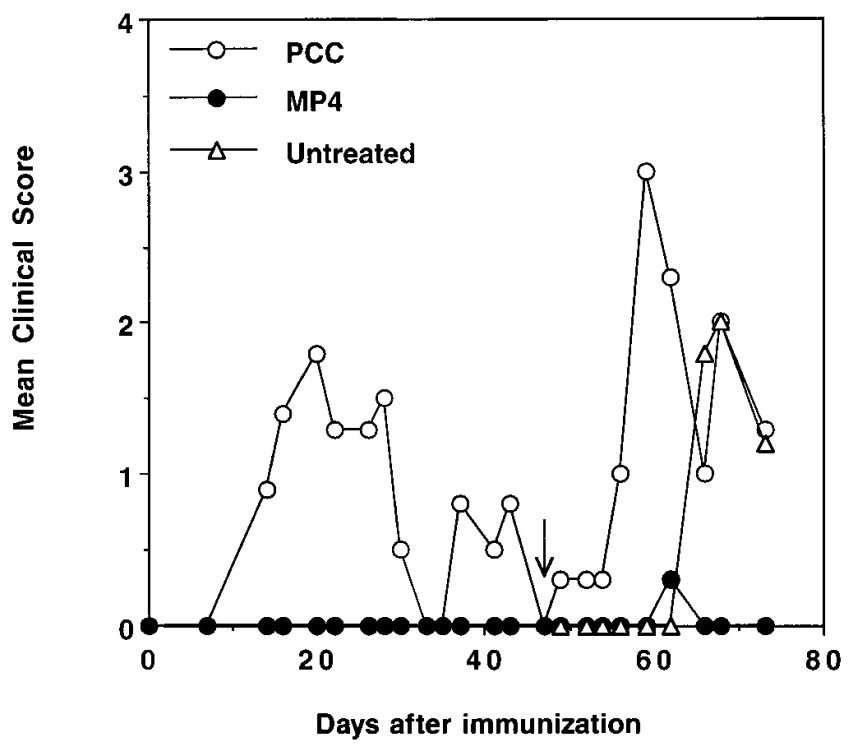

Figure 6. Mice treated with MP4 are resistant to the reinduction of EAE. Disease was induced in SJL/J mice with PLP139-151 peptide and pertussis. Mice were treated with PCC or MP4, as described in the legend of Fig. 2, and were rechallenged 6 wk later with the same antigen (arrow). Mice were monitored routinely, and a mean clinical score was assigned for each group of mice (six mice per group). A third group of mice consisting of age-matched naive recipient mice were immunized to control for disease induction with the second PLP139-151 peptide/CFA emulsion. This experiment is representative of two separate experiments.

(Fig. 7). Thus, MP4 therapy can ameliorate established disease and prevent further disease progression.

Detection of functional peptide-MHC complexes after MP4 administration. We hypothesized that the potency of MP4 could be related to the stability of the protein in vivo. As this might be reflected in the ability to detect complexes of peptides derived from MP4 in association with MHC molecules, we tested whether splenocytes from mice injected intravenously with MP4 could specifically activate MBP- and PLP-specific $\mathrm{T}$ cells. In these studies, spleens were removed from mice at various times after a single intravenous injection of $7.6 \mathrm{nmol}$ MP4, and the splenocytes used as APCs in proliferation assays with T cell lines specific for PLP139-151 and MBP87-99. The results shown in Fig. 8 demonstrate that strong antigen-specific proliferative responses of both MBP and PLP T cell lines were elicited by in vivo-pulsed splenic APCs. Splenic antigen presenting activity for PLP139-151 was rapid and peaked between 4 and $12 \mathrm{~h}$ after MP4 injection, as determined by the magnitude of the peptide-specific proliferative responses (Fig. $8 \mathrm{~A}$ ). Presentation of the MBP87-99 epitope was delayed, but also peaked between 4 and $12 \mathrm{~h}$ after injection of MP4 (Fig. $8 \mathrm{~B}$ ). The in vivo-pulsed spleens demonstrated significant antigenpresenting function, even as late as $24 \mathrm{~h}$ after the intravenous injection with MP4 (Fig. 8, $A$ and $B$ ). Spleen cells pulsed in vivo with PLP139-151 peptide showed little or no activation of the PLP-specific T cell line, even at $1 \mathrm{~h}$ after injection (data not shown). Prolonged APC function for MBP87-99- and PLP139151-specific $\mathrm{T}$ cell responses was also observed after separate injections of recombinant MBP21.5 and $\triangle \mathrm{PLP} 4$ proteins, respectively (data not shown). Interestingly, our preliminary re-

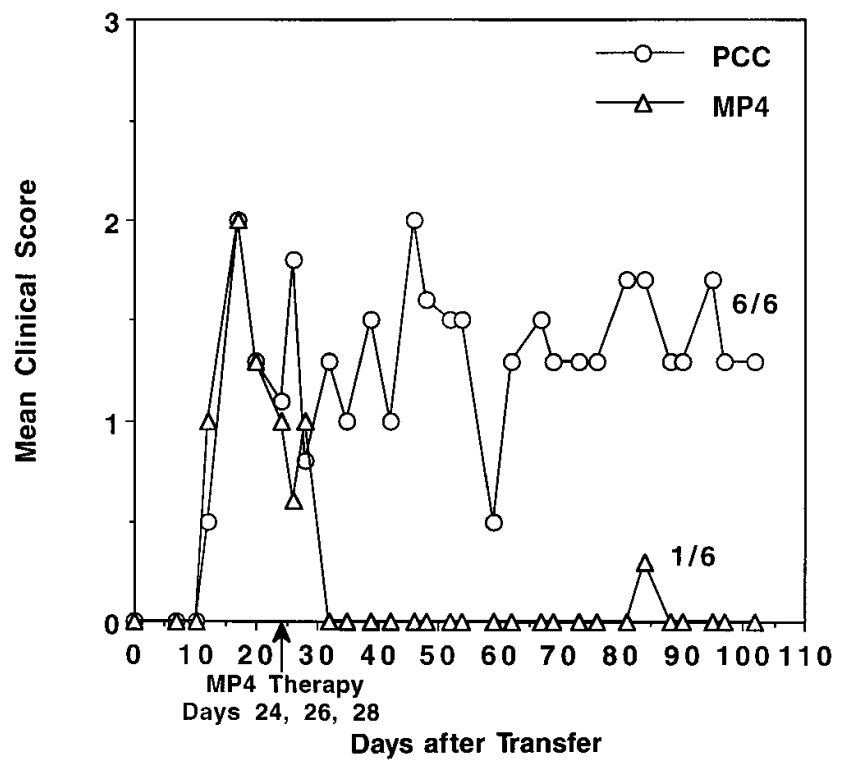

Figure 7. Reversal of clinical EAE by administration of MP4 after recovery from acute disease. Mice were monitored for the progression of clinical disease after the transfer of $5 \times 10^{6}$ PLP139-151-activated $T$ cell blasts intraperitoneally on day 0 . After recovery from the initial episode of disease (day 23 after cell transfer), mice were treated with MP4 (600 $\mu \mathrm{g} /$ day) or PCC on days 24,26 , and 28 , and were observed for the development of clinical relapses. The data are representative of two similar experiments, and are expressed as the mean clinical score for all mice in each treatment group as a function of days after $\mathrm{T}$ cell transfer. Incidence of clinical relapse during the observation period is indicated next to the corresponding clinical course.

sults suggest that more prolonged APC function is observed after intravenous administration of $\triangle \mathrm{PLP} 4$ relative to MBP21.5, which may reflect differences in the biophysical properties of the two proteins. If true, the kinetics of MBP-specific APC activity after injection of MP4 suggest that the bioavailability and tolergenic function of MBP21.5 may be prolonged by virtue of its covalent linkage to $\triangle$ PLP4 in the MP4 hybrid protein. Experiments to confirm this are underway. Overall, these results suggest that the in vivo stability or half-life of the intact proteins results in a more prolonged bioavailability of antigen-MHC complex presentation, as compared to individual peptides.

Prevention of EAE in mice with defective Fas expression. Intravenous antigen administration has been shown to cause peripheral $\mathrm{T}$ cell deletion $(21,23)$. One mechanism of this deletion may be attributed to Fas receptor-mediated activationinduced cell death (59). To examine the role of this mechanism in the intravenous therapy of EAE, the mutant fas gene $l p r$ was bred onto the SJL/J background by crossing SJL/J mice to MRL lpr/lpr mice. The resulting $\mathrm{F}_{1}$ hybrids were then backcrossed to $\mathrm{SJL} / \mathrm{J}$ mice, and their offspring were intercrossed to produce $\mathrm{H}-2^{\mathrm{s}}$ animals of either a wild-type $(+/+)$ or $l p r / l p r$ genotype. Since PLP is the most potent encephalitogen in active disease models in SJL/J mice (6), both wild-type and Fasdeficient mice were immunized with PLP peptide 139-151 in CFA. 5 d later, treatment was initiated with either control polypeptide or recombinant PLP $(\Delta \mathrm{PLP} 4)$. EAE of comparable severity was observed in both the wild-type and Fas-deficient mice (Table I). Surprisingly, however, intravenous therapy with $\triangle$ PLP4 completely prevented all clinical manifestations of 

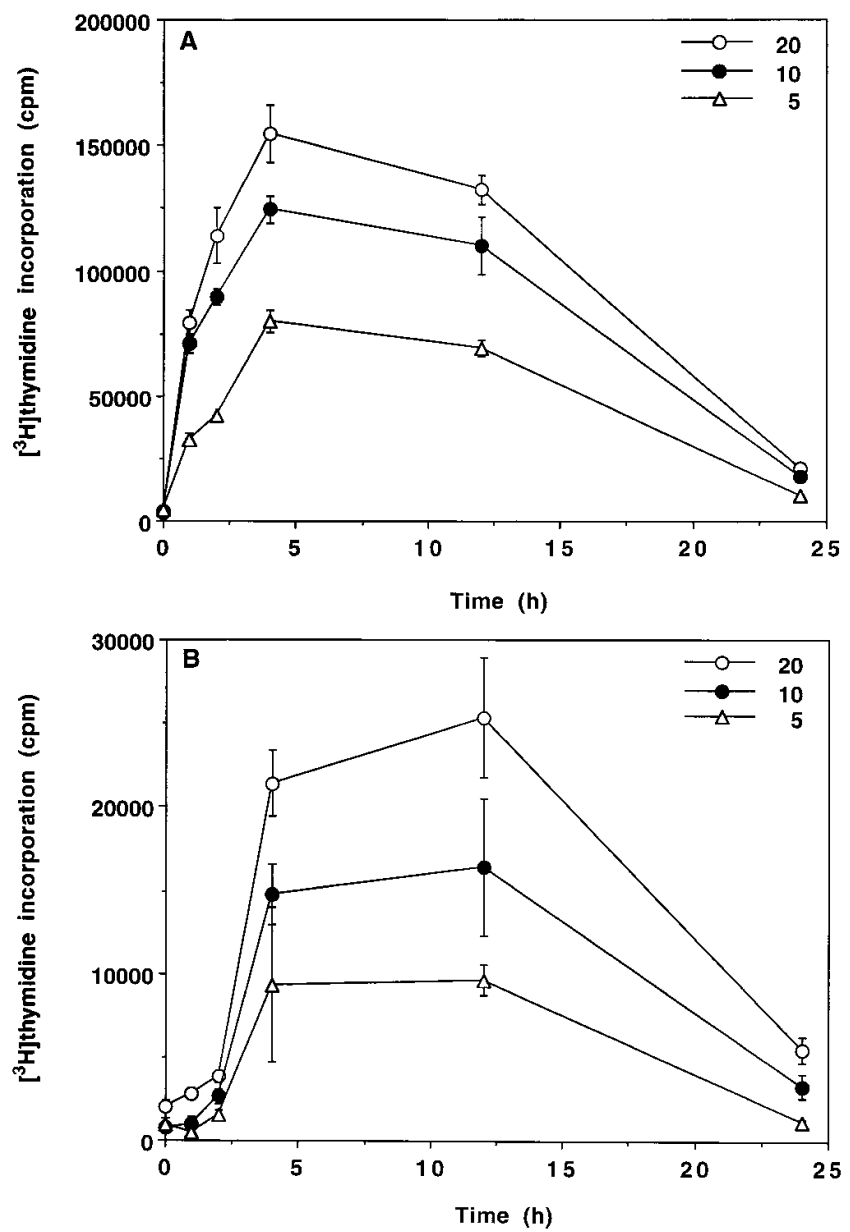

Figure 8. Peptide-MHC complexes formed in vivo are detectable in mice injected with MP4. Mice were injected intravenously with $300 \mu \mathrm{g}$ MP4 (7.6 nmol) at various time points before removal of spleens (0-24 h). Splenocytes from the injected mice were examined for their capacity to stimulate PLP139-151-specific $(A)$ and MBP87-99-specific T cells $(B)$. T cells were plated at $5 \times 10^{4}$ cells $/$ well. Mitomycin $\mathrm{C}$-treated splenocytes were plated into micotiter plates to achieve the indicated APC/T cell ratios. T cell proliferation is expressed as the mean cpm $( \pm$ SEM $)$ in triplicate wells. Background proliferation was between 974 and 2,942 cpm for the two lines. Maximal mean proliferation at $24 \mathrm{~h}$ for the MBP- and PLP-specific T cells was 5,494 and $20,831 \mathrm{cpm}$ relative to backgrounds with $T$ cells alone of $2,042 \mathrm{cpm}$ and 2,942, respectively. The results presented are representative of two separate experiments.

EAE in both groups (Table I). In analogous experiments, treatment with intact MP4 protein also prevented PLP139151-induced disease despite the absence of Fas (data not shown).

To examine the susceptibility of potentially encephalitogenic $\mathrm{T}$ cells from wild-type and Fas-deficient mice to activationdriven cell death, independent PLP-specific T cell lines were derived from wild-type and Fas-deficient mice that had been immunized with PLP peptide. To measure the induction of programmed cell death, PLP139-151 peptide plus IL-2-activated cells from each line were stimulated with anti-CD3 or anti-T cell receptor $\mathrm{mAb}$, and were examined for evidence of apoptosis by PI staining and flow cytometry. Whereas a significant percentage of Fas-positive, PLP-specific T cells were induced
Table I. Treatment with $\triangle P L P 4$ Protects Fas-deficient Mice from $E A E^{*}$

\begin{tabular}{lllcc}
\hline & & \multicolumn{3}{c}{ Clinical disease } \\
\cline { 3 - 5 } Fas genotype & Treatment & Incidence & MDO $^{\ddagger}$ & MMS $^{\S}$ \\
\hline$+/+$ & PCC & $7 / 7$ & $16.8 \pm 0.3$ & $4.0 \pm 0.8$ \\
$+/+$ & $\Delta$ PLP4 & $0 / 10$ & & \\
$-/-$ & PCC & $5 / 5$ & $17.9 \pm 0.8$ & $3.7 \pm 0.3$ \\
$-/-$ & $\Delta$ PLP4 & $0 / 8$ & & \\
\hline
\end{tabular}

*EAE was induced in mice by immunization with $150 \mu \mathrm{g}$ PLP peptide 139-151 emulsified in CFA before treatment on days $+5,+7$, and +9 with PCC or MP4. ${ }^{\ddagger} \mathrm{MDO}$, mean day of onset \pm SEM. ${ }^{\S} \mathrm{MMS}$, mean maximal disease severity \pm SEM

to undergo apoptosis, no evidence of apoptosis was observed after $\mathrm{mAb}$-mediated stimulation of the activated Fas-deficient, PLP-specific T cells, even using doses of anti-CD3 or anti-T cell receptor $\mathrm{mAb}$ as high as $100 \mu \mathrm{g} / \mathrm{ml}$ (Fig. 9). Several conclusions can be drawn from these findings. First, as expected, activated wild-type, PLP-specific T cells undergo programmed cell death in response to receptor-mediated stimulation, implicating this mechanism in the amelioration of EAE after systemic administration of recombinant antigens to normal mice. Second, the therapeutic efficacy of antigen treatment in Fasdeficient mice indicates further that systemic antigen administration can be tolerogenic despite deficient Fas expression, either through nondeletional mechanisms or possibly via nonFas-dependent pathways of $\mathrm{T}$ cell elimination in vivo $(63,64)$.

\section{Discussion}

In this study, we have demonstrated the efficacy of a recombinant MBP-PLP fusion protein, MP4, in the therapy of murine EAE. Our results clearly show that a single protein therapeutic can simultaneously induce tolerance to $\mathrm{T}$ cells specific for distinct epitopes in vivo and thereby prevent disease. Animals treated with MP4 developed no signs of clinical disease after induction either by active immunization with encephalitogen or by the adoptive transfer of activated encephalitogenic MBP- and PLP-specific T cell populations. Intravenous administration of MP4 abrogated both MBP- and PLP-specific immune responses in vivo and completely prevented the development of acute and relapsing EAE mediated by combined $\mathrm{T}$ cell populations specific for both encephalitogens.

Most importantly for potential application to patients with demyelinating disease, initiation of therapy with MP4 after disease onset resulted in a marked amelioration of the subsequent course of disease, with complete prevention of further relapses and normalization of the clinical disease score in the absence of any evidence of exacerbation of symptoms. Intravenous administration of MP4 was effective, even when delayed as late as $24 \mathrm{~d}$ after adoptive transfer of PLP-specific T cells. The ability of MP4 to abrogate established disease after induction by PLP peptide 139-151 is of particular interest in view of the observation by Miller and colleagues that relapses of EAE initially induced by immunization with PLP139-151 in SJL/J mice are mediated by newly activated $\mathrm{T}$ cells that are specific 
IL-2

IL-2 + anti-CD3

IL-2 + anti-TCR

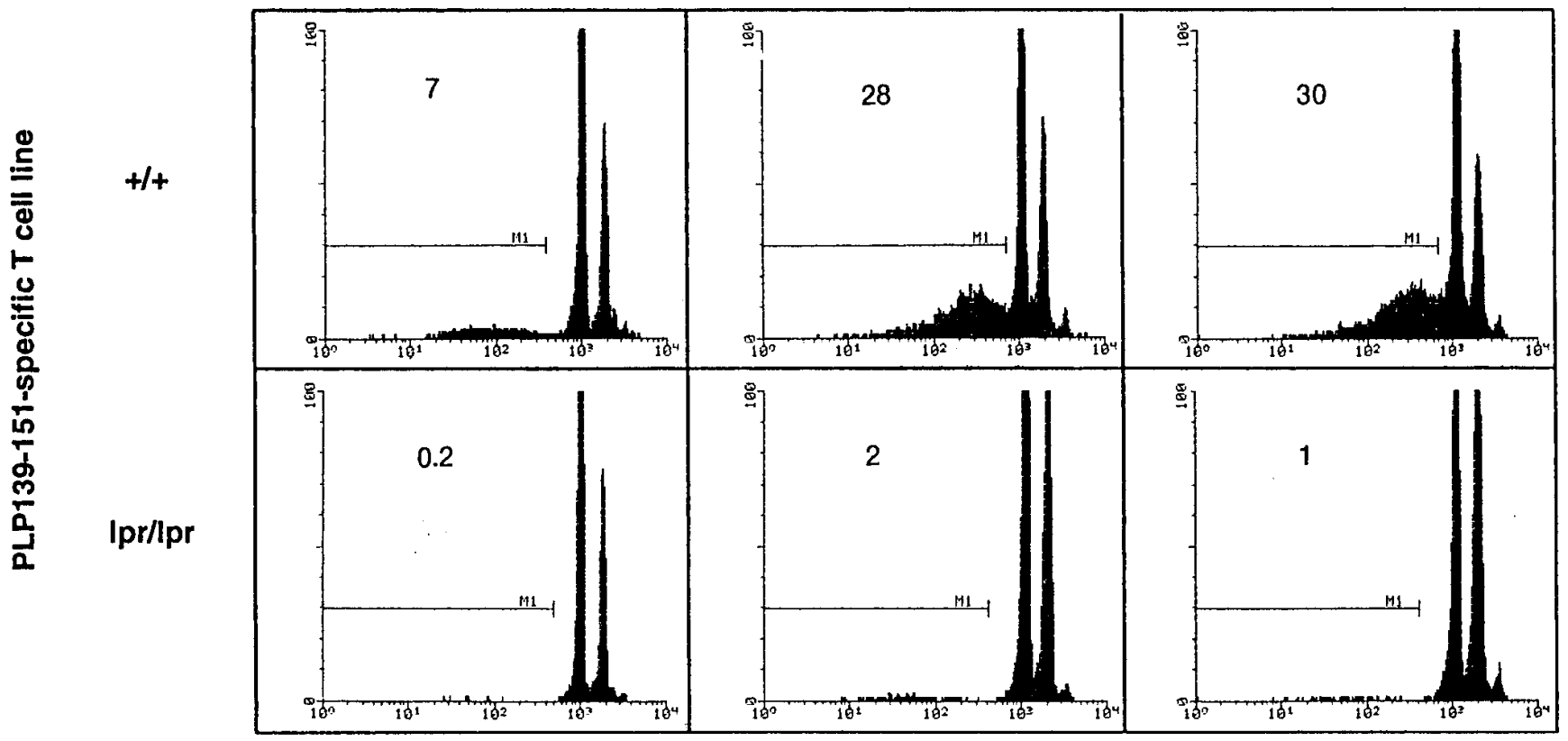

Figure 9. Apoptosis of wild-type (L100) and Fas-deficient (L101) T cells stimulated with anti-CD3 and anti-T cell receptor- $\alpha \beta$. PLP139-151-specific T cell lines from wild-type and Fas-deficient intercross mice were stimulated with PLP peptide 139-151 and mitomycin C-treated syngeneic splenocytes as APCs. $2 \mathrm{~d}$ later, viable cells were recovered and cultured with either $10 \mathrm{U} / \mathrm{ml}$ recombinant IL-2 or plate-bound anti-CD3 (2C11; $10 \mu \mathrm{g} / \mathrm{ml}$ ) or anti-T cell receptor- $\alpha \beta$ (H57-597; $10 \mu \mathrm{g} / \mathrm{ml}$; Pharmingen, San Diego, CA) in the presence of $10 \mathrm{U} / \mathrm{ml}$ rIL-2. Apoptosis of cells was assessed after $24 \mathrm{~h}$ in culture by incorporation of PI. The staining patterns represent data from one of three experiments.

for PLP peptide 178-191 and possibly MBP epitopes as well $(54,56)$. Although remaining to be tested directly, our results thus provide evidence for the efficacy of MP4 therapy in a setting where determinant spreading might have occurred.

The precise mechanism of tolerance induced by the intravenous administration of MP4 remains to be established. The abrogation of MBP and PLP-specific proliferative responses may be consistent with either clonal deletion, anergy, immune deviation to an antiinflammatory Th2 phenotype, a combination of mechanisms, or other as yet undefined mechanisms. It is very likely, however, that the efficacy of intravenous MP4 treatment in normal mice is at least in part accounted for by the deletion of MBP- and PLP-specific T cells in vivo. Several studies in $\mathrm{T}$ cell receptor transgenic model systems have directly demonstrated antigen-specific $\mathrm{T}$ cell deletion in lymphoid organs after systemic (intravenous or intraperitoneal) antigen administration $(21,23,59)$. For example, Lenardo and colleagues demonstrated that repeated intravenous injections with MBP resulted in the deletion of MBP-specific transgenic $\mathrm{T}$ cells and the prevention of EAE $(21,22)$. Recently, Singer and Abbas were able to directly correlate the deletion of transgenic T cells in peripheral lymphoid organs after systemic antigen administration with the expression of the Fas antigen, a TNF family receptor that transduces signals mediating programmed cell death (59). However, we have also shown that EAE can also be completely prevented by antigen administration to $\mathrm{H}-2^{\mathrm{s}}$ Fas-deficient mice. The absence of disease in the Fas-deficient animals could be accounted for by a Fas-independent pathway of antigen-driven clonal deletion, such as the recently described TNF-mediated induction of apoptosis in Fas-deficient $\mathrm{T}$ cell populations (63). Alternatively, it is possible that either antigen-driven clonal anergy or immune deviation could be induced in $\mathrm{T}$ cells that are defective in Fas expression, resulting in in vivo tolerance without $\mathrm{T}$ cell elimination. $\mathrm{Re}$ cent data reported by Van Parijs et al. with respect to the systemic administration of antigen in weak adjuvant have provided evidence in support of this notion (65).

The resistance of MP4-treated mice to the reinduction of EAE even several months after the initial immunization is of particular interest. It is possible that, in addition to inducing peripheral $\mathrm{T}$ cell tolerance, intravenous administration of MP4 could also mediate the clonal deletion of developing MBP- and PLP-specific T cell precursors during their maturation in the thymus. Studies in murine systems have clearly shown the deletion of thymocytes of both immature and mature phenotypes in response to systemic antigen injection $(66,67)$. If this is the case, intravenous antigen therapy has the capacity to induce long-lasting T cell tolerance that affects both mature peripheral $T$ cells as well as immature, newly developing autoreactive thymocyte populations, an outcome with positive implications for the treatment of individuals with chronic $\mathrm{T}$ cell-mediated autoimmune diseases.

We have previously shown that the components of MP4 can be processed to multiple epitopes on both MBP and PLP by APCs in vitro for presentation to various MHC-restricted, antigen-specific T cells (57; Elliott, E.A., R. Corfiell, T.M. Wilson, C.S. Raine, J.A. Wilkins, S.P. Squinto, L.A. Matis, and J.P. Mueller, manuscript in preparation). In the current study, we further demonstrate that after intravenous injection into $\mathrm{SJL} / \mathrm{J}$ mice, MP4 is effectively processed in vivo to the dominant encephalitogenic epitopes on both MBP and PLP. Consistent with the therapeutic efficacy of MP4 in the treatment of combined MBP- and PLP-mediated disease, functionally stable peptide-MHC complexes were detected in vivo, as demonstrated by the potent activation of PLP139-151 and MBP87- 
99-specific T cell lines elicited by splenic APCs from MP4injected mice. It has previously been suggested that the therapeutic potency of tolerogenic peptides might correlate with the duration with which functional peptide-MHC complexes can be detected in vivo after peptide injection (24). Thus, a variant peptide analogue of MBP, shown to be far more potent than the native peptide in the treatment of EAE, was distinguished from the native peptide by its ability to form stable peptideMHC complexes in vivo (24). Here, we have functionally demonstrated, for two distinct epitopes, the presence of such complexes for as long as $24 \mathrm{~h}$ after a single injection of MP4 protein, which is considerably longer than previously reported after the intravenous injection of short peptides (24). This finding may have significant implications with regard to the bioavailability and potency of protein, as compared to peptide therapeutics in the induction of in vivo $\mathrm{T}$ cell tolerance.

Inhibition of pathogenic $\mathrm{T}$ cell responses without concomitant generalized immunosuppression represents a paramount goal of immunotherapeutic approaches to autoimmune disease. Immunoreactivity to multiple autoantigens, including the recruitment of additional epitopes during the course of disease, presents a significant challenge for the development of antigen-specific therapies for $\mathrm{T}$ cell-mediated autoimmunity. From this perspective, the use of a soluble form of a therapeutic protein that can induce tolerance to multiple epitopes on MBP and PLP seems likely to be more effective than the use of individual peptides in antigen-specific therapy of MS. Moreover, our pharmacokinetic studies demonstrating the formation of multiple, long-lived functional peptide-MHC complexes in vivo after intravenous protein administration, which may correlate with therapeutic efficacy, provide additional rationale for the use of protein-based therapeutics as tolerogens.

Although additional antigens apart from MBP and PLP, including myelin oligodendrocyte glycoprotein, myelin-associated glycoprotein, and $\alpha \mathrm{B}$-crystallin, have been implicated as autoantigens in MS, there is considerable evidence that MBP and PLP, the predominant proteins of the myelin sheath, may represent important targets of autoimmune attack in this disease (27-47). The results presented here thus provide a persuasive rationale for the systemic administration of tolerance-inducing recombinant forms of these myelin proteins as an immunotherapy for MS.

\section{Acknowledgments}

We thank Jeff Bluestone for hamster anti-mouse CD3 mAb 2C11; Stefan Brocke for the I-A $\mathrm{A}^{\mathrm{s}}$-restricted, MBP-specific T cell line L1; Roberta Marks and Jennifer Katz for DNA sequence analysis; Jeff Burkwit and Bonnie Beck for expert technical assistance in the purification of recombinant MBP21.5, $\triangle$ PLP4, and MP4; and Michael J. Lenardo for suggestions and advice during the course of this study.

This work was performed as part of a Cooperative Research and Development Agreement (CRADA) between the National Institutes of Allergy and Infectious Diseases, National Institutes of Health, and Alexion Pharmaceuticals.

\section{References}

1. Martin, R., H.F. McFarland, and D.E. McFarlin. 1992. Immunological aspects of demyelinating disease. Annu. Rev. Immunol. 10:153-187.

2. Massacesi, L., C.P. Genain, D. Lee-Parritz, N.L. Letvin, D. Canfield, and S.L. Hauser. 1995. Active and passively induced experimental autoimmune encephalomyelitis in common marmosets: a new model for multiple sclerosis. Ann. Neurol. 37:519-530.
3. Touhy, V.K., R.A. Sobel, and M.B. Lees. 1988. Myelin proteolipid protein-induced experimental allergic encephalomyelitis. J. Immunol. 140:18681873.

4. Tuohy, V.K., Z. Lu, R.A. Sobel, R.A. Laursen, and M.B. Lees. 1988. A synthetic peptide from myelin proteolipid protein induces experimental allergic encephalomyelitis. J. Immunol. 141:1126-1130.

5. Tuohy, V.K., Z. Lu, R.A. Sobel, R.A. Laursen, and M.B. Lees. 1989. Identification of an encephalitogenic determinant of myelin proteolipid protein for SJL mice. J. Immunol. 142:1523-1527.

6. Kennedy, M.K., L.J. Tan, M.C. Dal Canto, V.K. Tuohy, Z. Lu, J.L. Trotter, and S.D. Miller. 1990. Inhibition of murine relapsing experimental autoimmune encephalomyelitis by immune tolerance to proteolipid protein and its encephalitogenic peptides. J. Immunol. 144:909-915.

7. Whitham, R.H., D.N. Bourdette, G.A. Hashim, R.M. Herndon, R.C. Ilg., A.A. Vandenbark, and H. Offner. 1991. Lymphocytes from SJL/J mice immunized with spinal cord respond selectively to a peptide of proteolipid protein and transfer relapsing demyelinating experimental autoimmune encephalomyelitis. J. Immunol. 146:101-107.

8. Whitman, R.H., R.E. Jones, G.A. Hashim, C.M. Hoy, R.-Y. Wang, A.A. Vandenbark, and H. Offner. 1991. Location of a new encephalitogenic epitope (residues 43-64) in proteolipid protein that induces relapsing experimental autoimmune encephalomyelitis in $\mathrm{PL} / \mathrm{J}$ and $(\mathrm{SJL} \times \mathrm{PL}) \mathrm{F}_{1}$ mice. J. Immunol. 147: 3803-3808.

9. McRae, B.L., M.K. Kennedy, L.-J. Tan, M.C. Dal Canto, K.S. Picha, and S.D. Miller. 1992. Induction of active and adoptive relapsing experimental autoimmune encephalomyelitis (EAE) using an encephalitogenic epitope of proteolipid protein. J. Neuroimmunol. 38:229-240.

10. Greer, J.M., V.K. Kuchroo, R.A. Sobel, and M.B. Lees. 1992. Identification and characterization of a second encephalitogenic determinant of myelin proteolipid protein (residues 178-191) for SJL mice. J. Immunol. 149:783-788.

11. Tuohy, V.K., R.A. Sobel, Z. Lu, R.A. Laursen, and M.B. Lees. 1992. Myelin proteolipid protein: minimum sequence requirements of active induction of autoimmune encephalomyelitis in SWR/J and SJL/J mice. J. Neuroimmunol. 39:67-74.

12. Miller, S.D., and W.J. Karpus. 1994. The immunopathogenesis and regulation of T cell mediated demyelinating diseases. Immunol. Today. 15:356-361.

13. Tuohy, V.K. 1994. Peptide determinants of myelin proteolipid protein (PLP) in autoimmune demyelinating disease: a review. Neurochem. Res. 19: 935-944.

14. Pettineli, C.B., and D.E. McFarlin. 1981. Adoptive transfer of experimental allergic encephalomyelitis in SJL/J mice after in vitro activation of lymph node cells by myelin basic protein: requirement for Lyt $1^{+} 2^{-} \mathrm{T}$ lymphocytes. J. Immunol. 127:1420-1423.

15. Fallis, R.J., C.S. Raine, and D.E. McFarlin. 1989. Chronic relapsing experimental allergic encephalomyelitis in SJL mice following the adoptive transfer of an epitope-specific T cell line. J. Neuroimmunol. 22:93-105.

16. Van der Venn, R.C., J.L. Trotter, H.B. Clark, and J.A. Kapp. 1989. The adoptive transfer of chronic relapsing experimental allergic encephalomyelitis with lymph node cells sensitized to myelin proteolipid protein. J. Neuroimmunol. 21:183-191.

17. Van der Venn, R.C., J.L. Trotter, W.F. Hickey, and J.A. Kapp. 1990 The development and characterization of encephalitogenic cloned T cells specific for myelin proteolipid protein. J. Neuroimmunol. 26:139-145.

18. Bitar, C.M., and C.C. Whitacre. 1988. Suppression of experimental autoimmune encephalomyelitis by oral administration of myelin basic protein. Cell. Immunol. 112:364-370.

19. Sharma, S.D., B. Nag, X.-M. Su, D. Green, E. Spack, B.R. Clark, and S Srivam. 1991. Antigen-specific therapy of experimental allergic encephalomyelitis by soluble class II major histocompatibility complex-peptide complexes. Proc. Natl. Acad. Sci. USA. 88:11465-11469.

20. Tan, L., M.K. Kennedy, M.C. Dal Canto, and S.D. Miller. 1990. Successful treatment of paralytic relapses in adoptive experimental autoimmune encephalomyelitis via neuroantigen-specific tolerance. J. Immunol. 147:1797-1802.

21. Critchfield, J.M., M.K. Racke, J.C. Zuniga-Pflucker, B. Cannella, C.S. Raine, J. Goverman, and M.J. Lenardo. 1994. T cell deletion in high antigen dose therapy of autoimmune encephalomyelitis. Science (Wash. DC). 263:11391143.

22. Racke, M.K., J.M. Critchfield, L. Quigley, B. Cannella, C.S. Raine, H.F. McFarland, and M.J. Lenardo. 1996. Intravenous antigen administration as a therapy for autoimmune demyelinating disease. Ann. Neurol. 39:46-56.

23. Kearney, E.R., K.A. Pape, D.Y. Loh, and M.K. Jenkins. 1994. Visualization of peptide-specific $\mathrm{T}$ cell immunity and peripheral tolerance induction in vivo. Immunity. 1:327-339.

24. Samson, M.F., and D.E. Smilek. 1995. Reversal of acute experimental autoimmune encephalomyelitis and prevention of relapses by treatment with a myelin basic protein peptide analogue modified to form long-lived peptideMHC complexes. J. Immunol. 155:2737-2746.

25. Nicholson, L.B., J. M. Greer, R.A. Sobel, M.B. Lees, and V.K. Kuchroo. 1995. An altered peptide ligand mediates immune deviation and prevents autoimmune encephalomyelitis. Immunity. 3:397-405.

26. Brocke, S., K. Gijbels, M. Allegretta, I. Ferber, C. Piercy, T. Blankenstein, R. Martin, U. Utz, N. Karin, D. Mitchell et al. 1996. Treatment of experi- 
mental encephalomyelitis with a peptide analogue of myelin basic protein. $\mathrm{Na}$ ture (Lond.). 379:343-346.

27. Martin, R., D. Jaraquemada, M. Flerlage, J.R. Richert, J. Whitaker, E.O. Long, D.E. McFarlin, and H.F. McFarland. 1990. Fine specificity and HLA restriction of MBP-specific cytotoxic T cell lines from MS patients and healthy individuals. J. Immunol. 145:540-548.

28. Ota, K., M. Matsui, E.L. Milford, G.A. Macklin, H.L. Weiner, and D.A. Hafler. 1990. T cell recognition of an immunodominant MBP epitope in MS. Nature (Lond.). 346:183-187.

29. Pette, M., K. Fujita, D. Wilkinson, D.M. Altman, J. Trowsdale, G. Giegerich, A. Hinkkanen, J.T. Epplen, L. Kappos, and H. Wekerle. 1990. Myelin autoreactivity in MS: recognition of myelin basic protein in the context of HLA DR2 products by T lymphocytes of MS patients and healthy donors. Proc. Natl. Acad. Sci. USA. 87:7968-7972.

30. Olsson, T., J. Sun, J. Hillert, B. Hojeberg, H.P. Ekre, G. Andersson, O. Olerup, and H. Link. 1992. Increased numbers of T cells recognizing multiple myelin basic protein epitopes. Eur. J. Immunol. 22:1083-1087.

31. Chou, Y.K., D.N. Bourdette, H. Offner, R. Whitham, R.-Y. Wang, G.A. Hashim, and A.A. Vandenbark. 1992. Frequency of T cells specific for myelin basic protein and myelin proteolipid protein in blood and cerebrospinal fluid in multiple sclerosis. J. Neuroimmunol. 38:105-114.

32. Valli, A., A. Sette, L. Kappos, C. Oseroff, J. Sidney, G. Miescher, M. Hochberger, E.D. Albert, and L. Adorini. 1993. HLA class II molecules and their recognition by T cells from MS patients. J. Clin. Invest. 91:616-628.

33. Markovic-Plese, S., H. Fukaura, J. Zhang, A. Al-Sabbagh, S. Scottwood, A. Sette, V.K. Kuchroo, and D.A. Hafler. 1995. T cell recognition of immunodominant and cryptic proteolipid protein epitopes in humans. J. Immunol. 155: 982-992.

34. Ben-Jun, A., R.S. Liblau, L. Cohen, D. Lehmann, E. Tournier-Lasserve, A. Rosenzweig, J. Zhang, J.C.M. Raus, and M.-A. Bach. 1991. Restricted T-cell receptor $\mathrm{V} \beta$ usage by myelin basic protein-specific T-cell clones in multiple sclerosis: predominant genes vary in individuals. Proc. Natl. Acad. Sci. USA. 88: 2466-2470.

35. Meinl, E., F. Weber, K. Drexler, C. Morelle, M. Ott, G. SaruhanDireskenelli, N. Goebels, B. Ertl, G. Jechart, G. Giegerich, et al. 1993. Myelin basic protein-specific T lymphocyte repertoire in MS. J. Clin. Invest. 92:26332643.

36. Joshi, N., K. Usuku, and S. Hauser. 1993. The T cell response to myelin basic protein in familial MS: diversity of fine specificity, restricting elements, and TCR usage. Ann. Neurol. 34:385-393.

37. Zhang, J.S., S. Markovic-Plese, B. Lacet, J. Raus, H.L. Weiner, and D.A. Hafler. 1994. Increased frequency of interleukin 2-responsive T cells specific for myelin basic protein and proteolipid protein in peripheral blood and cerebrospinal fluid of patients with multiple sclerosis. J. Exp. Med. 179:973-984.

38. Chou, Y.K., R.E. Jones, D. Bourdette, R. Whitman, G. Hashim, J. Atherton, H. Offner, and A.A. Vandenbark. 1994. Human myelin basic protein (MBP) epitopes recognized by mouse MBP-selected T cell lines from multiple sclerosis patients. J. Neuroimmunol. 49:45-50.

39. Shanmugam, A., C. Copie-Bergman, S. Caillat, J.F. Bach, and E. Tournier-Laserve. 1995. In vivo clonal expression of T lymphocytes specific for an immunodominant $\mathrm{N}$-terminal myelin basic epitope in healthy individuals. J. Neuroimmunol. 59:165-172.

40. Trotter, J.L., W.F. Hickey, R.C. van der Veen, and L. Sulze. 1991. Peripheral blood mononuclear from multiple sclerosis patients recognize myelin proteolipid protein and selected peptides. J. Neuroimmunol. 33:555-562.

41. Pelfrey, C.M., J.L. Trotter, L.R. Tranquill, and H.F. McFarland. 1993. Identification of a novel $\mathrm{T}$ cell epitope of human proteolipid protein (residues 40-60) recognized by proliferative and cytolytic $\mathrm{CD}^{+} \mathrm{T}$ cells from multiple sclerosis patients. J. Neuroimmunol. 46:33-42.

42. Pelfrey, C.M., J.L. Trotter, L.R. Tranquill, and H.F. McFarland. 1994. Identification of a second $\mathrm{T}$ cell epitope of human proteolipid protein (residues 89-106) recognized by proliferative and cytolytic $\mathrm{CD}^{+} \mathrm{T}$ cells from multiple sclerosis patients. J. Neuroimmunol. 53:153-161.

43. Correale, J., W. Gilmore, M. McMillan, S. Li, K. McCarthy, T. Le, and L.P. Weiner. 1995. Patterns of cytokine secretion by autoreactive proteolipid protein-specific $\mathrm{T}$ cell clones during the course of multiple sclerosis. J. Immunol. 154:2959-2968.

44. Correale, J., M. McMillan, K. McCarthy, T.Le, and L.P. Weiner. 1995. Isolation and characterization of autoreactive proteolipid protein $\mathrm{T}$ cell clones from multiple sclerosis patients. Neurology. 45:1370-1378.

45. Sun, J.-B., T. Olsson, W.-Z. Wang, B.-G. Xiao, V. Kostulas, S. Fredrikson, H.-P. Ekre, and H. Link. 1991. Autoreactive T and B cells responding to myelin proteolipid protein in multiple sclerosis and controls. Eur. J. Immunol. 21:1461-1468.

46. Sobel, R.A., J.M. Greer, and V.K. Kuchroo. 1994. Minireview: autoimmune responses to myelin proteolipid protein. Neurochem. Res. 19:915-921.

47. Ohashi, T., T. Yamamura, J. Inobe, T. Kondo, T. Kunishita, and T. Tabira. 1995. Analysis of proteolipid protein (PLP)-specific T cells in multiple sclerosis: identification of PLP 95-106 as an HLA-DR2,w15-associated determinant. Int. Immunol. 7:1771-1778.

48. McCarron, R.M., R.J. Fallis, and D.E. McFarlin. 1990. Alternations in T cell antigen specificity and class II restriction during the course of chronic relapsing experimental allergic encephalomyelitis. J. Neuroimmunol. 29:73-79.

49. Perry, L.A., E. Barzaga-Gilbert, and J.L. Trotter. 1991. T cell sensitization to proteolipid protein in myelin basic protein-induced relapsing experimental allergic encephalomyelitis. J. Neuroimmunol. 33:7-15.

50. Lehman, P.V., T. Forsthuber, A. Miller, and E.E. Sercarz. 1992. Spreading of $\mathrm{T}$ cell autoimmunity to cryptic determinants of an autoantigen. Nature (Lond.). 358:155-157.

51. Cross, A.H., V.K. Touhy, and C.S. Raine. 1993. Development of reactivity of new myelin antigens during chronic relapsing autoimmune demyelination. Cell. Immunol. 146:261-269.

52. Fritz, R.B., and M. Zhao. 1994. Encephalogenicity of myelin basic protein exon-2 peptide in mice. J. Neuroimmunol. 51:1-8.

53. Segal, B.M., C.S. Raine, D.E. McFarlin, R.R. Voskuhl, and H.F. McFarland. 1994. Experimental allergic encephalomyelitis induced by the peptide encoded by exon 2 of the MBP gene, a peptide implicated in remyelination. $J$. Neuroimmunol. 51:7-19.

54. McRae, B.L., C.L. Vanderlugt, M.C. Dal Canto, and S.D. Miller. 1995 Functional evidence for epitope spreading in the relapsing pathology of experimental autoimmune encephalomyelitis. J. Exp. Med. 182:75-85.

55. Zhao, M-L., and R.B. Fritz. 1995. The immune response to a subdominant epitope in myelin basic protein exon- 2 results in immunity to intra- and in termolecular dominant epitopes. J. Neuroimmunol. 61:179-184.

56. Miller, S.D., C.L. Vanderlugt, D.J. Lenschow, J.G. Pope, N.J Karandikar, M.C. Dal Canto, and J.A. Bluestone. 1995. Blockade of CD28/B7 1 interaction prevents epitope spreading and clinical relapses in murine EAE. Immunity. 3:739-745.

57. Nye, S.H., C.M. Pelfrey, J. Burkwitt, R.R. Voskuhl, M.J. Lenardo, and J.P. Mueller. 1995. Purification of immunologically active $21.5 \mathrm{kDa}$ isoform of myelin basic protein. Mol. Immunol. 32:1131-1141.

58. Studier, F.W., A.H. Rosenberg, J.J. Dunn, and J.W. Dubendorff. 1990 Use of T7 RNA polymerase to direct expression of cloned genes. Methods Enzymol. 185:60-89.

59. Singer, G.G., and A.K. Abbas. 1994. The Fas antigen is involved in peripheral but not thymic deletion of $\mathrm{T}$ lymphocytes in $\mathrm{T}$ cell receptor transgenic mice. Immunity. 1:365-371.

60. Matis, L.A., M. Bookman, and S.A. Rosenberg. 1987. Cloning with antigens and interleukin-2 of murine $\mathrm{T}$ lymphocytes having distinct functions. Methods Enzymol. 150:343-351.

61. Nicoletti, I., G. Migliorati, M.C. Pagliacci, F. Grignani, and C. Riccardi. 1991. A rapid and simple method for measuring thymocyte apoptosis by propidium iodide staining and flow cytometry. J. Immunol. Methods. 139:271-279.

62. Lindsey, J.W., M. Pappolla, and L. Steinman. 1995. Reinduction of experimental autoimmune encephalomyelitis in mice. Cell. Immunol. 162:235-240.

63. Zheng, L., G. Fischer, R.E. Miller, J. Peschon, D.H. Lynch, and M.J.

Lenardo. Induction of apoptosis in mature $\mathrm{T}$ cells by tumor necrosis factor. 1995. Nature (Lond.). 377:348-351.

64. Tucek-Szabo, C.L., S. Andejelic, E. Lacy, K.B. Elkon, and J. NikolicZugic. 1996. Surface T cell Fas receptor/CD95 regulation, in vivo activation, and apoptosis. J. Immunol. 156:192-200.

65. Parijs, L.V., A. Ibraghimov, and A.K. Abbas. 1996. The roles of costimulation and Fas in T cell apoptosis and peripheral tolerance. Immunity. 4:321-328.

66. Murphy, K.M., A.B. Heimberger, and D.Y. Loh. 1990. Induction by antigen of intrathymic apoptosis of $\mathrm{CD}^{+} \mathrm{CD} 8^{+} \mathrm{TCR} \gamma \delta$ thymocytes in vivo. Science (Wash. DC). 250:1720-1723.

67. Liblau, R.S., R. Tisch, K. Shokat, X-D. Yang, N. Dumont, C.C. Goodnow, and H.O. McDevitt. 1996. Intravenous injection of soluble antigen induces thymic and peripheral T-cell apoptosis. Proc. Natl. Acad. Sci. USA. 93:30313036.

68. Weimbs, T., and W. Stoffel. 1992. Proteolipid protein (PLP) of CNS myelin: positions of free, disulfide-bonded, and fatty acid thioester-linked cysteine residues and implications for the membrane topology of PLP. Biochemistry. 31: 12289-12296. 